\title{
Les listes marginales de la óklah de Halle
}

Bruno OGNIBENI

Pontificia Universitá Lateranense, Roma

Dans la bibliothèque universitaire (plus exactement Universitäts- und Landesbibliothek Sachsen-Anhalt) de Halle est conservé (avec la cote $\mathrm{Y}$ b $4^{\circ} 10$ ) un des deux manuscrits complets de la collection massorétique connue sous le nom de 'oklah we'oklah. La première partie de cet important manuscrit a été éditée par F. Díaz Esteban (Sefer 'okhlah we-'okhlah, Madrid 1975, TECC 4) et la seconde par moi-même (B. Ognibeni, La seconda parte del sefer 'oklah we'oklah, Madrid-Fribourg 1995, TECC 57).

Le texte de la 'okllah we'oklah est donc déjà entièrement à la disposition des chercheurs. Restent encore inédites les listes copiées dans les marges du manuscrit de Halle, qui ne font pas partie de la 'oklah originale, mais ont été ajoutées après coup par au moins trois mains différentes.

Je les édite ici, telles que je peux les lire dans le microfilm. Je leur ai donné une numérotation progressive, en ajoutant, entre parenthèses, le numéro de la feuille où elles se trouvent, suivi de $r$ (recto) ou v (verso). Deux listes (aux ff. 63v et 83r) se sont avérées illisibles, à cause de la marge supérieure de la feuille coupée ou pliée.

En général, elles se rattachent, par leur contenu, aux listes écrites dans la même page dans les marges de laquelle elles sont copiées. Dans le commentaire de Ch. D. Ginsburg (The Masso- 
rah Translated into English with a Critical and Exegetical Commentary, Londres 1905) elles sont en effet citées généralement avec le numéro de la liste de la collection, suivie de la mention «marge»: par exemple mon $\S 4$ est cité en Ginsburg dans son commentaire à waw $\S 26$ comme "Halle Ochlah VeOchlah Halle I, § 24, margin». Ailleurs, il préfère donner le numéro de la feuille: par exemple mon $\S 8$ est cité en alef $\S 21$ comme "Halle Ochlah Ve-Ochlah, fol. 51b, in the upper margin".

Il faut préciser à ce propos que j'ai adopté la numérotation en chiffres arabes placée en haut de la feuille au milieu, tandis que Ginsburg adoptait celle en lettres hébraïques dans le coin gauche. Cette dernière (qui commence avec i, témoignant par là que le manuscrit a perdu ses premières six feuilles) est sans doute plus ancienne, mais moins précise, car elle répète la f. 3 et saute une feuille entre les קיט

Onze listes ont été copiées dans les marges même si elles se rencontraient déjà dans le texte de la collection. Ce sont les suivantes:

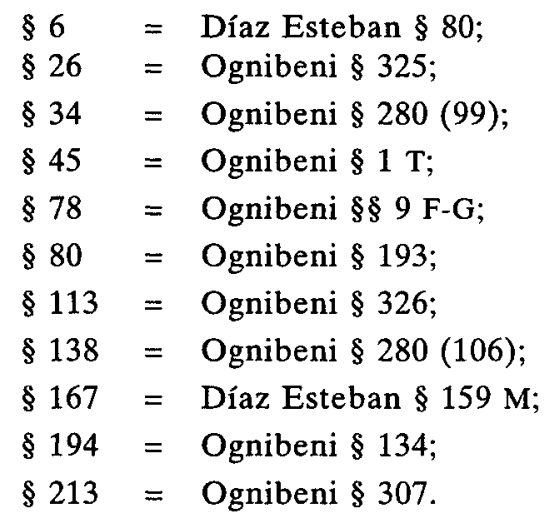

Il peut arriver que dans la même page nous trouvions une liste à la fois dans le texte et dans la marge: par exemple à la f. 78r les 3 אמָ ple pleins et les 3 dectifs. Les listes marginales n'avaient donc pas comme seul but de compléter la collection, mais aussi de transmettre d'autres traditions parallèles.

Douze listes se rencontrent aussi dans la 'oklah de Paris (éditée au siècle dernier par S. Frensdorff, Das Buch Ochlah W'Ochlah, Hannover 1864): 


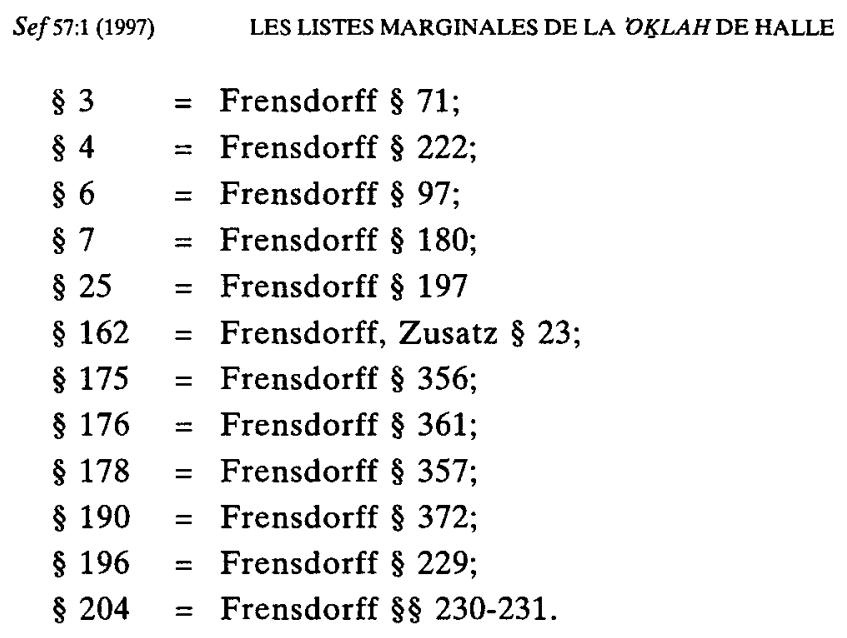

$\S 3=$ Frensdorff $\S 71$;

$\S 4=$ Frensdorff $\S 222$;

$\S 6=$ Frensdorff $\S 97 ;$

$\S 7=$ Frensdorff $\$ 180$;

$\S 25=$ Frensdorff $\S 197$

$\S 162=$ Frensdorff, Zusatz § 23;

$\S 175=$ Frensdorff $\S 356$;

$\S 176=$ Frensdorff $\S 361$;

$\S 178=$ Frensdorff $\$ 357$;

$\S 190=$ Frensdorff $\S 372$;

$\S 196=$ Frensdorff $\S 229$;

$\S 204=$ Frensdorff $\S \S 230-231$.

Notons enfin que l'on peut rencontrer deux fois la même liste dans les marges en différents endroits, même rapprochés:

$$
\begin{aligned}
& \S 14 \text { (f. } 52 \mathrm{v} \text { ) = § } 212 \text { (f. 116r); } \\
& \S 75 \text { (f. } 76 \mathrm{v} \text { ) }=\$ 161 \text { (f. 95r); } \\
& \S 83 \text { (f. } 78 \mathrm{v} \text { ) }=\$ 84 \text { (f. } 79 \text { r). }
\end{aligned}
$$

Quand il y a des données divergentes, les massorètes ne suppriment pas l'une au profit de l'autre, mais les juxtaposent, à cause de leur respect pour la tradition.

A la fin de chaque liste, $j$ 'indique les correspondances avec d'autres sources massorétiques éditées. Ce sont d'abord l'editio princeps de la massore, réalisée par Ya'aqov ben Hayyim (Venise 1524-1525, citée selon l'index alphabétique se trouvant à la fin du quatrième volume; à défaut, selon le lieu biblique en marge duquel se trouve la liste); la grande compilation de Ginsburg (The Massorah Compiled from Manuscripts, Alphabetically and Lexically Arranged, 3 vols., Londres 1880-1885; le vol. III, n'étant pas ordonné alphabétiquement, est cité selon la page); la grande massore du codex de Leningrad éditée par G. Weil (Massorah gedolah iuxta codicem Leningradensem B 19 a, Rome 1971), citée selon le numéro de la liste; celle du codex d'Alep éditée par D. S. Löwinger (Massora magna of the Aleppo Codex, Jérusalem 1978), également selon le numéro de la liste; celle du codex du Caire éditée sous la direction de F. Pérez Castro ( $E l$ códice de Profetas de El Cairo: Edición de su texto y masoras, 
Madrid 1979-1992), citée selon le lieu biblique; celle enfin de l'autre manuscrit du même massorète du codex de Leningrad, éditée par M. Breuer (The Masorah Magna to the Pentateuch by Shemuel ben Ya aqov, New York 1992), citée selon la page.

Concernant l'édition de Löwinger, il faut souligner qu'elle n'est pas complète, car elle commence avec le livre de Josué, laissant de côté (ce qui est assez étonnant) les soixante-dix listes qui se trouvent dans la fin du Deutéronome. Ces dernières avaient été d'ailleurs déjà éditées par le même Löwinger dans son article "The Aleppo Codex and the Ben Asher Tradition", Textus 1 (1960) pp. 59-111. Je les citerai avec le sigle Aleppo suivi du numéro de page de la revue.

\section{\& 1 (f. 19v)}

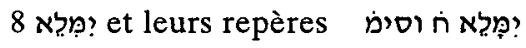

2 S 23,7

2 R 3,17

Is 6,4

Jr 13,12 bis

Ps 71,8

Ps 126,2

Pr 20,17

b. Hayyim, מל (9); Ginsburg, mem § 384; Weil, Mm 1854; Cairo, Jr 13,12.

\section{§ 2 (f. 19v)}

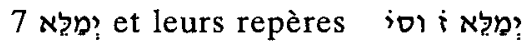

Lv 8,33

Lv 16,32

$1 \mathrm{R} 13,33$

Is 65,20

Ps 20,5

Ps 20,6

Jb 8,21

le dernier écrit $h e$

ומפתח אהל מועד ואשר ימלא את ידו ודו

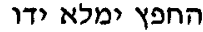

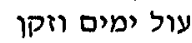
וכל עצתך ימלא ומיא ימלא על כל משאלתיך

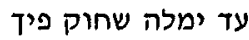

b. Hayyim, מל (5); Ginsburg, mem \& 392; Weil, Mm 706; Löwinger, Is $\S 364$.
\&3 (f. 27r)

אi מן חד וחד אריש [mots i ו בריש תיבותא קמ ולית דכi וס; waw au début du mot avec qamez, uniques, et leurs repères

Ex 9,15 וٕרך

Nb 21,7 (ㄱ)

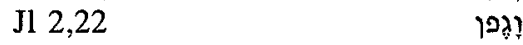

? ודו?

So 3,12 ודר

Ez 2,10 ורזה

Ex 38,28 ורורים

Pr 21,8 וז

Est 8,15 וחור

Jr 40,7 ๆ

2 R 10,15 ש?

Ex 2,12 וכד

Gn 45,23

Gn 11,30

Ex 10,8 ומי

Jr 2,19 ומר

Is 5,12 נובְל

Is 19,6 וְסוף

Jr 29,23 )

Lv 7,23 ?ועי 
Dt 3,11

1 R 10,19

2 R 7,12

Jr 2,24

Jb 26,9

Dn 2,7

Dn 10,14

Jr 49,10

Jr 52,33

Ez 14,4

Ps 81,4

Dn 6,11

Frensdorff, \& 180; Ginsburg, hé § 35 a; Weil, Mm 2035.

\section{$\S 8$ (f. $46 v)$}

13 mots écrits alef au lieu de hé [à la fin du mot] et leurs repères

Nb 11,20

$\mathrm{Nb} 32,37$

$1 \mathrm{R} 4,18$

$\mathrm{Ez} 31,5$

1 Ch 11,44

Jb 38,11

Ps 127,2

Esd 6,8

Dn 11,44

Lm 3,12

1 Ch 2,49?

?

Rt 1,20

b. Hayyim, א (8); Ginsburg, alef $\S$ 21.

\section{$\S 9$ (f. 50v)}

8 écrits עינו mais lus y et leurs repères

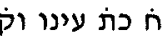
עיניו וסימ עיפ

$1 \mathrm{~S} 3,2$

1 S 3,18

בחמא למר כמר כמטרא במאט גיעא כמטרא

החלו כהות עחוזיות ולא כחדו כחות
$2 \mathrm{~S} 13,34$

2 S 24,22

Jr 32,4

Jb 21,20

2 S 19,19

Pr 6,13

ויברח

תראינה

כידו תואינה

ועברה העברה כיווה

קרץ בעינו העברו

b. Hayyim, עי (4); Ginsburg, 'ain § 315; Weil, Mm 1543; Löwinger, Pr $\S 22$; Cairo, 1 S 3,2.

\section{$\S 10$ (f. 52v)}

ה הוא דאנון et leurs repères

צדיקיא וסימ דאנון

1 Ch 1,27

Ex 6,26

Ex 6,27

אברם הוא אברהם

$1 \mathrm{~S} 17,14$

2 Ch 26,1 ?

הוא אהרן ומשה המרה הואים

הוא משה ואהרן ומשה

דוד הוא הקטן משת ואון הוא עזיהו הואו הקוד

et inversement וחלופ הוא ה ה ד

דאנון רשיעיא qui sont impies הוא 5 et leurs repères וסיט

נמרוד הוא היה גבור ציד

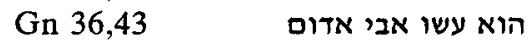

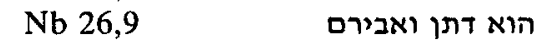

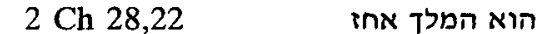

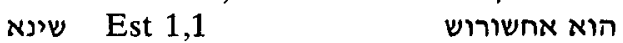
למה Ginsburg, hé \& 86; Weil, Mm 3908.

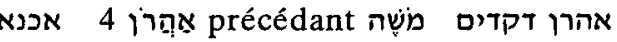
למשה דं וסיט

Ex 6,20

Ex 6,26

1 Ch 5,29

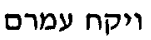

ובני עמרם אהרן ומשרו ומרים Nb 3,1

et tous ceux des Chro- וכל דברי niques comme eux ומים דכרים b. Hayyim, (20); Ginsburg, alef § 177; Breuer, 290. 
$\$ 12$ (f. 52v)

כל יָד דסמוך להזקה קמץ דסמוך לאזכרה

פתח יד רוד

Tous les 7 suivis de $m e z$; et tous ceux suivis du tétragramme ont patah.

\section{$\S 13$ (f. 52v)}

היא ג בלשן

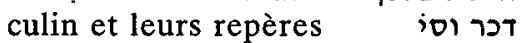
Gn 34,14

Nb 15,25

$\mathrm{Nb} 18,19$

כי חרפה היא לנו כי שגגה היא מיאית לית

Breuer, 197-198.

$\S 14$ (f. 52v)

6 ?ִ pleins et leurs repères

Gn 5,29

Dt 21,7

Ne 5,5

Os 14,4

Ps 90,17 bis ברית מלח עולם היא

b. Hayyim, ๆ' (8); Ginsburg, yod $\S$ 97; III, 207; Löwinger, Ps \& 243.

\section{$\$ 15$ (f. 53v)}

3 versets de 7 mots

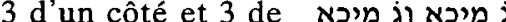

l'autre et le mot central est והוא? et leurs repères

Gn 49,20

Is 32,8

Jb 28,23

מאשר שמנה לחמו אונדיב נדיבות יעמת לחמו אלהים הבין דרכה נדיבות ונדינ

b. Hayyim, in (4); Ginsburg, hé $\S$ 94; Breuer, 267.

\section{$\S 16$ (f. 55r)}

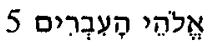
et leurs repères

אלהי העבריס ה וסימי
Ex 5,3

Ex 9,1

Ex 7,16

Ex 9,13

Ex 10,3

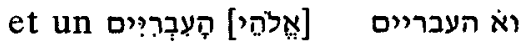
b. Hayyim, אל (66); Ginsburg, alef § 672; Weil, Mm 427.

\section{$\S 17$ (f. 55v)}

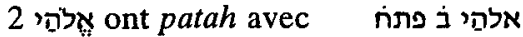
באתן וסימj

בחרתי הסתופף בבית אלהי שמרה נפשי כי חסיד אנית אלחי

b. Hayyim, (44); Ginsburg, alef § 678; Weil, Mm 960.

\section{$\S 18$ (f. 56r)}

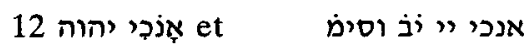
leurs repères

\section{Ex 4,11}

Ex 20,2

Dt 5,6

Ex 20,5

Dt 5,9

Is 44,24

Is 43,11

Is 51,15

Os 12,10

Os 13,4

2 S 7,18

Ps 81,11

מי שם פה לאדם

אשר הוצאתיך לאדם וחברו תורו

פקד עון אבות וחברו ערו ערו

אנכי "י עשרה כל אנכיו

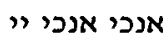
ואנכי "י אלהיך אנכיך רגעי עוד אושיבך באהלים יחים ואלהים זולתי לא תוד ביעם

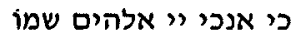
אנכי "י אלהיך המעלך ניחי

b. Hayyim, אד (125); Ginsburg, alef $\S 970$.

\section{$\S 19$ (f. 56r)}

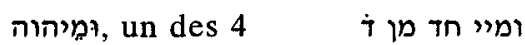

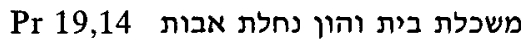

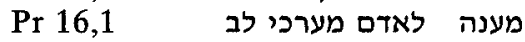
כל משפטו בחיק יוטל את מדת Pr 16,33

רבים מבלים מבשים פני נדיב Pr 29,26 
b. Hayyim, א (29); Ginsburg, yod $\S 207$; Weil, Mm 3623; Löwinger, Pr $\S 90$.

\section{$\S 20$ (f. 56r)}

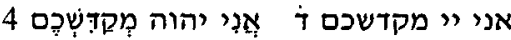
et leurs repères

וסימי

Ex 31,13 ואתה דבר אל בני ישראל דשבת Lv 20,8

Lv 21,8

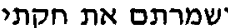

Lv 22,32

וקדשתו כי את לחם חקם

ולא תהללו את שם קדי לחם

b. Hayyim, אד (74); Ginsburg, alef § 953; Weil, Mm 775; Breuer, 394.

\section{$\$ 21$ (f. 56v)}

6 ניהוה au début du verset avec l'accent

רי וֹ רא פס בט revi' $a$ et leurs repères

Gn 19,24

1 R 5,26

Jl 2,11

Jon 1,4

$\mathrm{Jb} 42,10$

Jb 42,12

רביע וסימ רמס

b. Hayyim, אד (31); Ginsburg, yod § 198; Weil, Mm 3567; Cairo, 1 R 5,26 et J1 2,11.

\section{$\S 22$ (f. 57r)}

11 appelées אִי

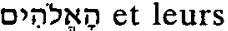
repères

Moïse

Elqana

Samuel

David

Shemayah

Micah

Amos

Elie

Elisée

Iddo

אלישע

Hanan fils

עדו מלינות

de Gedalyah

b. Hayyim, (45); Ginsburg, alef $\S 425$.

\section{$\S 23$ (f. 57v)}

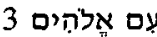

Gn 32,29

$1 \mathrm{~S} 14,45$

Jb 34,9

עם אלהים ذ

שרית

עשה היום

ברצתו עיתו

b. Hayyim, (68); Ginsburg, 'ain $\S$ 636; Weil, Mm 242; Löwinger, Jb $\S 132 ;$ Breuer, 194.

\section{$\S 24$ (f. 57v)}

8 מלאך האלהים ח וסימנ

Gn 31,11 ויאמר אלי מלאך האלהים Ex 14,19 ויסע מלאך האלהים מלאר השחים Jg 6,20

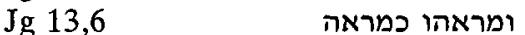
Jg 13,9 וישמע " בקול מנוח כמראח 2S ואדני חכם וירגל בעבדך אל אדני

b. Hayyim, אל (87); Ginsburg, mem § 409; Breuer, 181.

\section{$\S 25$ (f. 57v)}

7 groupes de 2 [mots] זוגין מן כל מו

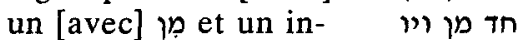
nerse et leurs repères nלוף מוסי מוי שמואל שלתנח
Ex 5,23

Jr 44,18

2 S 22,49

Ps 18,49

2 S 22,4

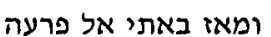
ומן אז חדלנו בתי ומלו ומקמי תרוממני חולנו אף מן קמי תרוממני תממי ומאיבי אושע תמי 
Ps 18,4 \$ \$מן איבי אושע דתהלות

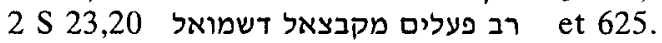

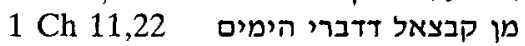

Jr 31,16

Ps 116,8

Ps 75,7

Dn 9,25

Esd 5,11

Dn 6,11 ועיניך מדמעה דיברי את עיניך מן דמעה

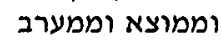

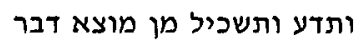

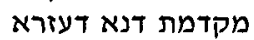
מן קדמת דנא דדניאל דנור

Dans la rubrique il faut corriger ו ו א ו et 1 ).

b. Hayyim, מ (15); Frensdorff, $\S$ 197; Ginsburg, mem § 19.

\section{$\S 26$ (f. 58r)}

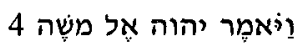
avec l'accent [zarqa] et leurs repères

Ex 4,21

Ex 8,1

Ex 8,12

Ex 9,8 ויאמר "י דנהרות ועל היארים

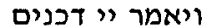
ויאמר " דפיח כבשן וכנים

b. Hayyim, אם (76); Ginsburg, alef § 860; Weil, Mm 395; Ognibeni, § 325 .

\section{§ 27 (f. 59r) \\ 4 אִילִ pleins dans le Pentateuque et leurs repères}

Gn 32,15

רחלים מאתים

ואת פר החטאת ואת שני האילים בנה לי בזה שבעה מזבחת קדפ

Dt 32,14 המאת בקר

et un défectif ... ... on וח

Ex 15,11 מי כמכה באלם

Il faut corriger la rubrique, retranchant le waw du premier mot.

b. Hayyim, (20); Ginsburg, alef

\section{$\S 28$ (f. 61v)}

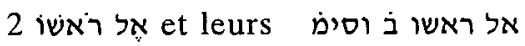
repères

Ex 36,29

ויחדו יהיו תמים

2 R 9,6

ויקם ויבא הביתה תמיתה

b. Hayyim, רא (77); Ginsburg, alef $\S 613$; Weil, Mm 635; Breuer, 416.

\section{$\S 29$ (f. 61v)}

6 mots ... tous uniques, et leurs לית דכוס וסין repères

$1 \mathrm{~S} 2,24$

Rt 1,13

אַל בני בניתי

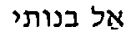
אַל אודות בנותי אַל באני אודות ואַַל כסיל בני אַל מות כסות אַל בנותי מותי

et tous ...

וכל דס לתלין comme eux, sauf un Jr 51,3 ואל ידרך הדורך

Ginsburg explique cette liste comme un "partially illegible fragment ... which registers some of the words representing letters Aleph and Beth in combination with and which is another piece of this [scil. la liste qu'il édite, qui est celle de b. Hayyim] alphabetical list".

L'explication de Ginsburg ne me semble pas convaincante. Je n'arrive pas à comprendre exactement les deux rubriques, mais les simanim montrent assez clairement l'intention de cette liste: dans la première partie, on enregistre des mots exceptionnellement précédés 


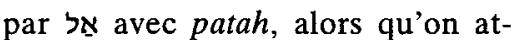
tendrait אֶ avec segol (logiquement, car ils sont tous des substantifs); dans la seconde, on enregistre un mot exceptionnellement précédé par אֶ, avec segol, alors qu'on attendrait אָ avec patah (puisque c'est une forme verbale).

b. Hayyim, (20); Ginsburg, alef $\S 496$.

\section{$\S 30$ (f. 62r) \\ 3 אֶל מקוֹם [אֶָר et leurs repères}

אל מקום ג וסימ

Gn 1,9

Qo 3,20

Qo 6,6

הכל חולך אל מקום הכים אל מקום אחד הכל הולך מקום

Il faut corriger la rubrique, y insérant le mot אָָ qui est tombé.

b. Hayyim, קס (28); Ginsburg, alef $\S 588$; Weil, Mm 3700 .

\section{§ 31 (f. 62v) \\ 4 אֶל 4 , et leurs repères}

Gn 49,29

Ez 13,19

Am 7,15

Am 8,2

et un [ואל עמפי]

Jl 4,3

b. Hayyim, עם (14); Ginsburg, alef § 599; Weil, Mm 364; Cairo, Ez 13,19 et Am 7,15; Breuer, 269.

\section{$\S 32$ (f. 63r)}

\section{5 et leurs repères}

Ex 28,35

ותחללנה אותי אי ומי ויני

\section{על אהרן ה וסi} והיה על אהרן
Ex 29,21

Ex 28,43

Ex 32,1

Lv 8,30
והזית על אהרן והיו על אהרן ועל בנריו ויקהל העם על אהרן ותל בניו ויז על אהרן

b. Hayyim, (22); Ginsburg, ain § 393; Weil, Mm 567.

\section{$\S 33$ (f. 63r)}

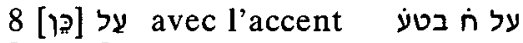
[pazer] et leurs repères

io)

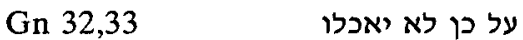
1 Ch 14,11 1 S 5,5 על כן חרה ארף " ערני בעמון

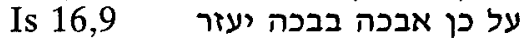

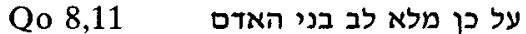

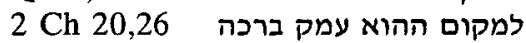
על כן קראו לימים האלה פורים

Il faut corriger la rubrique, $y$ insérant le mot $\rceil$, qui est tombé.

b. Hayyim, נ (3); Ginsburg, 'ain § 458; Weil, Mm 3781.

\section{§ 34 (f. 63v)}

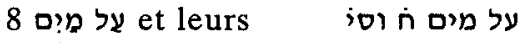
repères

Lv 14,5

Lv 14,50 Jr 17,8 ? ?

Jr 51,13

Ez 17,5 אמך כגפן בדמך על מים שתולה Ez 19,10 b. Hayyim, מי (17); Ginsburg, ain § 468; Weil, Mm 739; Löwinger, Ez § 123; Breuer, 487; Ognibeni, $\S 280,99$. $\S 35$ (f. 64r)

3 versets où il y a פסון דאית בהון

ו מלין דמין לא באית 
où on ne met pas waw, נסבין וספו חד un au début du verset, רא פסבו וסו et leurs repères

Ex 22,8

Lv 21,20

Pr 23,29

על כל דבר פשע

או גבן אל דבר דקש

למי ארי למי אבוי אבוי

Il s'agit de trois versets où le même mot (y en Ex 22,8; ix en Lv 21,20; למ̣en Pr 23,29) revient six fois sans être jamais précédé de la conjonction waw.

b. Hayyim, Ex 22,8 et $\operatorname{Lv} 21,20$; Ginsburg, waw $\S 123$.

\section{$\S 36$ (f. 65v)}

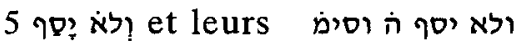
repères

Gn 38,26

Dt 5,22

$\mathrm{Jg} 13,21$

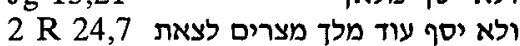

1 S 15,35

עוד לדעתה קול גדול מלעתר

b. Hayyim, D' (23); Ginsburg, lamed $\S 188$; Weil, Mm 1084; Cairo, Jg 13,21; Breuer, 689-690.

\section{$\$ 37$ (f. 66r)}

לוא לה מל וסימ 35 bleins et לוא leurs repères

בי לוא אוכל לקום מפניך

Lv 5,1

אל בני כי לא טובה השמועה 2,24

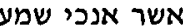

1 S 19,4

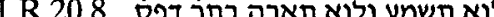

2 R 5,17

$1 \mathrm{R} 22,18$

2 R 6,12

Jr 2,25

Jr 2,31

Jr 3,3

Jr 3,12

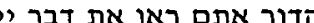

וימנעו ריבים ומלקוש לוא לוא היה

לוא אפיל פני בכם ומלקו

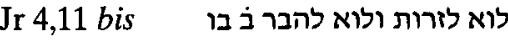

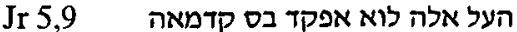

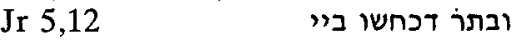

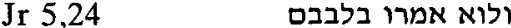
הוסרי ירושלם נולוא שמעו קדמ דויקשו את ערפם

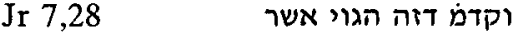

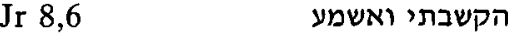

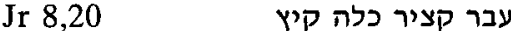

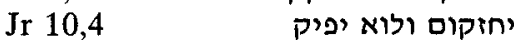

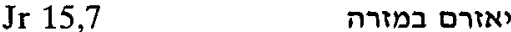

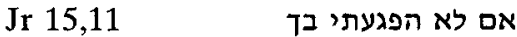

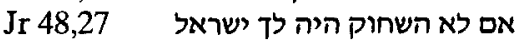
אם יסחבום קדמי ליח לד ישרל

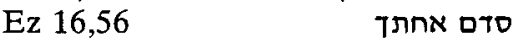

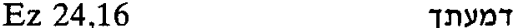
Oוא אבוא בעיר נדרשתי ללוא שאלו נמצאתי ללוא בקשוני ליכואי לוא אליכם כל עברי דרך b. Hayyim, לא (24); Ginsburg, lamed § 75; Weil, Mm 681; Löwinger, Sam $\S 146 ;$ Jr § 30; Ez § 103; Breuer, 186187.

\section{$\S 38$ (f. 66r)}

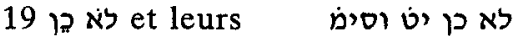
repères

Gn 48,18

Ex 10,11

$\mathrm{Nb} 12,7$

Dt 8,14

2 S 18,14

2 S 20,21

2 S 23,5

2 R 7,9

2 R 17,9

Jr 8,6

Jr 48,30 bis

Jr 48,30 ?

Is 10,7

Is 16,6

Ps 1,4

Pr 15,7

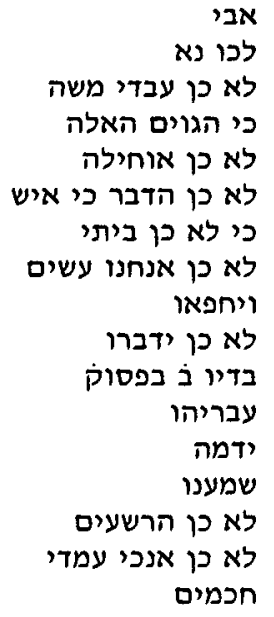


b. Hayyim, د (1); Ginsburg, lamed $\S 102$; Weil, Mm 436; Breuer, 263 264.

\section{$\S 39$ (f. 67v)}

Un des 3 [לא] trompeurs parce qu'on comprend לו et leurs repères

Ex 22,24

Ex 23,13

Dt 16,19

לא תשימון עליו נשך לא ישמע על פיד עליך

b. Hayyim, (14); Ginsburg, lamed $\S 79$.

\section{$\S 40(f .67 v)$}

ללא יאג וסיט

Am 6,13

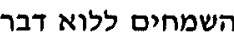

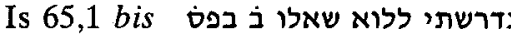
2 Ch 15,3

Os 2,25

Jb 39,16

Jb 26,2

Jb 26,3 ללא כהן מורה ליה עמיה ללא עמי עמי אתה מורח ליח ליה

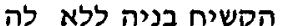

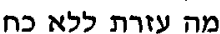

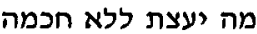

2 Ch 15,3 bis וימים רבים לישראל ל בפסט

Une main postérieure a ajouté à la fin וחד וללא תורה, 'et un וּלְליא', 2 Ch 15,3 .

Une autre main a ajouté au-dessus "הלא הדחתם את כהני, siman de 2 Ch 13,9, qui avait été omis dans la liste.

b. Hayyim, לא (27); Ginsburg, lamed $\S$ 253-254; Weil, Mm 2442.

\section{$\S 41$ (f. 68r)}

12 mots défectifs yod i on מלין dans la racine venue et leurs repères בלשן ביאה מלין וסיח

Ex 13,11 Ex 15,17
Dt 26,9

Jos 7,23

Ex 19,4

Jr 17,26

Jr 24,1

Jr 25,9

Jr 35,2

Ez 8,5

Ez 20,10

Ez 27,26

במים רבים חבאוך חמור האר

b. Hayyim, (51); Ginsburg, bet $\S 144$.

\section{§ 42 (f. 68r)}

ותבאנה ה וסימ repères

Gn 41,21

Ex 2,18

Ex 2,16

Is 48,3

אל קרבנה אל רעואל קרנה ותבאנה ותדלנה b. Hayyim, (38); Ginsburg, bet § 135; Weil, Mm 301.

\section{$\S 43$ (f. 68r)}

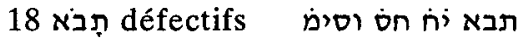
et leurs repères

Gn 49,6

Ex 23,27

Lv 12,4

Dt 1,37

Dt 17,14

Dt 23,26

Dt 23,25

Dt 24,10

Dt 27,3

2 S 13,5

1 R 22,25

Jr 2,3

$\mathrm{Jb} 1,7$

Jb 2,2
בסדם אל תבא נפשי

את אימתי ואל המקדש אישת גם בי התאנף המקי היד בכרם רעך רעי בעף כי תשה ברעד רעך וכתבת עליחן ברען תבא נא תמר אחתי קדמ' חדר בחדר דמלכים נשמר ליתי קיור קדש ישראל ליי מאין תבא ישרא אי מזה תבא תבא
אשימה עלי מלך רתי בקמת רעד עלי רעי 
Lm 1,22

$\mathrm{Jb} 3,24$

Jb 29,13

תבא כל רעתם

כי לפני לחמי רעי

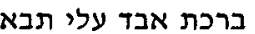

Cette liste a perdu sa seconde partie: "et comme eux tous ceux des Proverbes, sauf 4 pleins" ( $P r$ $3,25 ; 4,14 ; 23,10 ; 26,2)$.

b. Hayyim, (29); Ginsburg, bet $\S 122 ;$ Weil, Mm 1769; Breuer, 265-266.

\section{$\S 44$ (f. 68v) \\ Un des 9 (mots) dé- fectifs alef dans la racine venue et leurs וסימנ בלשון repères}

בי על יום טוב בנו דשמואל 25,8 S

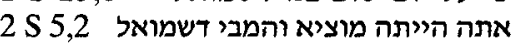

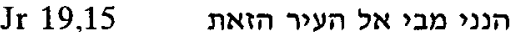

1 R 21,21 הנני מבי אליך רעה דאחי העחב 1 R 21,29 לא אבי הרעה בימיו

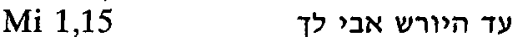

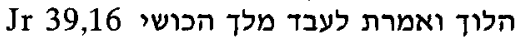

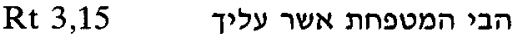
2 Ch ויבו ירבעם דדברי הימים

b. Hayyim, (72); Ginsburg, bet § 66; Löwinger, Rois § 220; Cairo, Mi 1,15 .

$\S 45$ (f. 68v)

3 מובאים ג וסיפ repères

Gn 43,18

Ez 30,11

Ez 23,42

על דבר הכסף

מובאים לשחת הספר הארץ מובים מובאים סבאים ממרח הארץ

b. Hayyim, (21); Ginsburg bet $\S$ 184; Weil, Mm 323; Cairo, Ez 30,11; Breuer, 242; Ognibeni, § $1 \mathrm{~T}$.

\section{$\S 46$ (f. 68v)}

7 ורֵאת oxytones et leurs repères
Gn 6,18

Ex 3,18

Dt 26,3

Zc 6,10

Dt 17,9 $\S 75$; III, 213; Weil, Mm 50; Cairo, 1 S 20,19; Jr 36,6; Zc 6,10.

\section{$\S 47$ (f. 69r)}

תבואנו ג וסימj et leurs repères תבְוֹאֶּוּ 3 Jb 20,22

Pr 10,24 כל יד עמל תבואנו

Pr 11,27 מגורת רשע היא תמל תבואנו היאו תואו

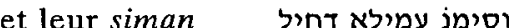
[araméen] בישא עמילא

b. Hayyim, בא (76); Ginsburg, bet § 125; Weil, Mm 3597.

\section{§ 48 (f. 69r)}

יבוֹא pleins dans le Pentateuque et leurs repères

Gn 32,9

Gn 32,12

Lv 11,34

Lv 14,8

Lv 16,26

Lv 16,28

$\mathrm{Nb} 8,24$

ובוא ז מל בתור וסימ

b. Hayyim, (66); Ginsburg, bet $\S 109$ a.

\section{$\S 49$ (f. 69r)}

Tל תחלות Th ceux des Psaumes et Job et Proverbes ומיוב ומשלי

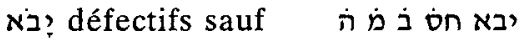
5 pleins, et leurs מל וסימ repères

Ps 71,18 ובאת ז בטע לרע

וסימנ Jb 5,21 לא תירא משוד כי יבוא
לכל יבוא גבורתך 
Jb 13,16

Jb 22,4

Jb 41,5

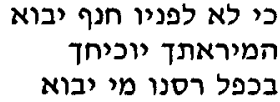

Ginsburg, bet $\S 110^{*}$ (tiqqunim au vol. 1); Löwinger, Jb $\S 18$.

\section{$\S 50$ (f. 69r)}

9 pạ pleins et leurs repères

Gn 42,15

Dt 31,11

2 R 5,18

2 R 12,10

$\mathrm{Ez} 46,8$

Ez 46,9

Ps 51,2

Ps 52,2

Pr 18,3

בבוא ט מל וסיט

בבוא אליכם בבוא כל ישראל איכם בבוא אדני בית רמון כל כל כיוא

בבוא איש בית "הית רמוא ובבוא הנשיא בבוא עם הארץ התוא בבוא אליו נתן הנביא בבוא דואג האדומי נתומי בבוא רשעי דואי

b. Hayyim, (32); Ginsburg, bet \& 84; Weil, Mm 2069; Breuer, 235.

\section{$\S 51$ (f. 69v)}

בוא יח מל וסימ 18 pleins, et leurs repères

Gn 24,31
Gn 39,16
Gn 43,25
Lv 25,22
Jos 10,27
2 R 16,11
Is 2,10
Ez 33,22 bis
Ez 38,18
Jl 3,4
Ml 3,23
Ag 1,2
Jb 14,14
Dn 11,10
Dn 11,13

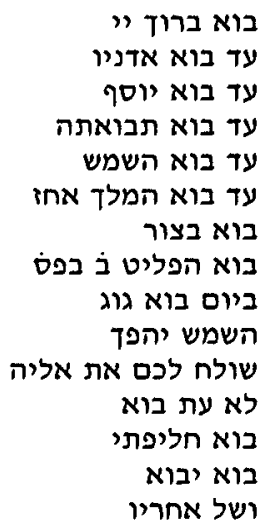

A la fin de la liste une autre עתה בוא כתבה על לוח main a ajouté אתם (Is 30,8).

b. Hayyim, בא (48); Ginsburg, bet $\S$ 80 b; Weil, Mm 169; Breuer, 144.
$\$ 52$ (f. 69v)

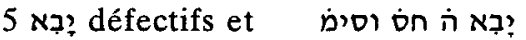
leurs repères

Nb 6,10 וביום השמיני יבא Ps 78,29 ותאותם יבא להם איש יבא בפריו

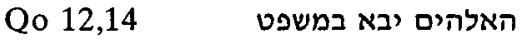
נוגם אלהיהם עם נסיכיכיהם עם כלי חמדתם אלחם

b. Hayyim, (52); Ginsburg, bet $\S 167$; Weil, Mm 871; Breuer, 565.

\section{$\S 53$ (f. 69v)}

et הַבְיאתִתיו 4 leurs repères

Gn 43,9

$\mathrm{Nb} 14,24$

Is 48,15

$1 \mathrm{~S} 1,22$

הביאתיו ד וסימ

אנכי אערבנו

ועבדי כלב אערבו הביאתיו והצליח דרכו יעלו עד יגמל הנער וחליח

b. Hayyim, (37); Ginsburg, bet $\S 149$ b; Breuer, 241.

\section{$\S 54$ (f. 69v)}

והביאה ذ וסימ repères

אל בני אהרן הכהנים

אל הכהן אלני מרון חכחנים

Ginsburg, bet $\S 153$; Breuer, 435.

$\S 55$ (f. 70r)

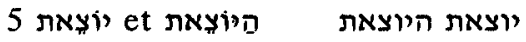

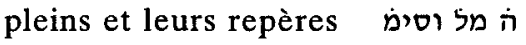

Am 5,3 Zc 5,3 ואת האלה היוצאת מאתיר ושל אחריו ושל אחריו אין פרץ אריץ

b. Hayyim, Y (25); Ginsburg, yod $\S 498$. 
$\S 56$ (f. 70v)

9 iأيّ pleins et leurs repères

\section{Ex 7,15 \\ Ex 8,25 \\ Ex 11,4 \\ Jos 6,1 \\ Jg 1,24 \\ $1 \mathrm{~S} 18,16$ \\ 2 S 19,8 \\ Ez 1,13}

et tous ceux des $\mathrm{Ha}$ giographes comme eux, sauf un

Ps 19,6

יוצא ט מל וסימי

המימה קדמ מעמך ממימד

בתוך מצרים ויריחו סגרת מצים ויראו השמרים סגרת ויפורים יוצא ובא לפניהם השים ועתה קום צא ובאיח ונגה לאש קום ועי וכל כתיל דدוأ ذ $\dot{~}$ והוא כחתן

b. Hayyim, Y' (31); Ginsburg, yod $\S 493$ b; Weil, Mm 1268; Cairo, Jos 6,1; Breuer, 297-298.

\section{$\S 57$ (f. 71r)}

הוצא ה וסימ

Gn 19,12

Lv 24,14

Jg 6,30

Jg 19,22

2 R 10,22

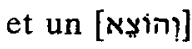

Ex 3,10

והוצא את עמי

b. Hayyim, Y' (29); Ginsburg, yod § 511; Weil, Mm 802; Cairo, Jg 6,30 et 19,$22 ; 2$ R 10,22 ; Breuer, 117-118.

\section{\$ 58 (f. 71v)}

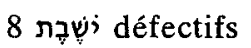
et leurs repères

Lv 15,23

2 R 4,13

Jos 2,15

2 R 22,14

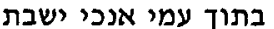

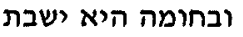
והיא ישבת בירושלם ישבת ובים
Jr 21,13

Zc 1,11

Zc 7,7

Ez 27,3

b. Hayyim, שי (16); Ginsburg, $\S$ 690; Weil, Mm 2184; Breuer, 490.

\section{$\$ 59$ (f. 72r)}

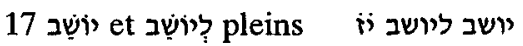
dans le Pentateuque, מל בת וסימב לימ et leurs repères

Gn 24,3

Gn 24,62

Gn 50,11

Ex 18,14

Ex 34,12

Ex 34,15

$\mathrm{Nb} 13,19$

$\mathrm{Nb} 13,29$ ter

$\mathrm{Nb} 21,34$

Dt 1,4 bis

Dt 2,31

Dt 4,46

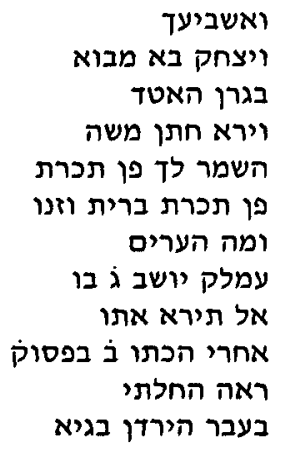

Le siman ראה החלתי est barré: au-dessous de la ligne, un correcteur a écrit le siman exact: "איאמר אלי אל תירא אתו כי בידך (Dt 3,2).

b. Hayyim, ש்' (17); Ginsburg, yod $\S 667$.

\section{§ 60 (f. 73r)}

שבו ה בתi teuque et leurs repères וסימ בתו

Gn 22,5

Gn 34,10

Ex 16,29

Ex 24,14

Nb 22,19

עם החמור שבו וסחרוה תמור שבו איש תחתיו שבו לנו בזה תמש תמתי ועתה שבו נא בזה אשר היא ישבת עליו

b. Hayyim, (32); Ginsburg, yod $\S 658$. 
$\S 61$ (f. $73 v$ )

9 וישבו ט בק dans la Bible et leurs repères

וסימי וער

$\mathrm{Nb} 31,9$

2 R 5,2

1 S 30,2

1 Ch 5,21

$2 \mathrm{Ch} 14,14$

2 Ch 28,8

2 Ch 21,17

2 Ch 28,17

2 Ch 28,5

Dans la rubrique le $\dot{0}(=9)$ est écrit au-dessus d'un ñ $(=8)$ barré. Le siman de 2 R 5,2 est écrit audessus de la ligne: la liste originale comprenait donc huit cas, sans $2 \mathrm{R} 5,2$. On y a ajouté ce dernier, et corrigé par la suite le chiffre dans la rubrique.

b. Hayyim, שב (47); Ginsburg, shin $\S \S 56$ et 57; Weil, Mm 1694

\section{$\S 62$ (f. 74r)}

9 pleins et leurs repères

ויקומו ט מל וסימ

Gn 24,54

$\mathrm{Nb} 22,14$

Jg 20,19

$1 \mathrm{~S} 23,24$

$1 \mathrm{~S} 31,12$

1 Ch 10,12

2 R 7,7

Esd 1,5

Ne 9,3

ויאכלו וישתו חוא

ויקומו שרי מואב קדם זיא בני ישר דגבעה שרימה וילכו זיפה דגבו כל איש חיל ויל

וחברו

וינסו בנשר האפרו ראשי האבות בנשת על עמדם ראי המתות

b. Hayyim, קם (32); Ginsburg, qof $\S$ 129; Weil, Mm 1663; Cairo, Jg 20,19 .

\section{$\S 63$ (f. 74r)}

4 versets où en chaque mot il y a shin [ou $\sin$ ]

ש וסיס et leurs repères

$\mathrm{Nb} 26,24$

$\mathrm{Nb} 26,31$

Ct 1,1

1 Ch 1,24

לישוב משפחת

ואשריאל משר

שיר השירים

שם ארפכשד שיר

b. Hayyim, $w(2)$; Ginsburg, shin $\S$ 18; III, 275.

$\S 64$ (f. 74r)

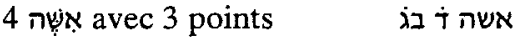
[= segol] et leurs נקדות וס; repères

ולקחת אתם מידם והקטרת 29,25

המזבחה ולקת הת ואת

Lv 8,21 ואת הקרב ואת הכרעים רחץ

במים וקת

Lv 8,28 ויקח משה אתם מעל כפיהם והקרבתם אשה עלה ליי דפסח מפסח

et tous ceux suivis de lamed comme

וכל דס ללמד נקות נוסות נותות eux avec 3 points

דכוֹ בג נקדות ללמד

b. Hayyim, אש (6); Ginsburg, alef $\S 1134$.

\section{$\S 65$ (f. $74 v$ )}

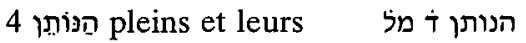
repères הנותן רוזנים לאין הנותן למלכים

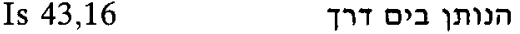
האל הנותן נקמות דיף לי

b. Hayyim, נת (36); Ginsburg, nun $\S$ 501; Weil, Mm 3436; Cairo, Is 40,23 .

\section{$\S 66$ (f. 74v)}

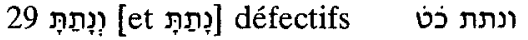
et leurs repères ונסת וסיט 
Gn 40,13

Ex 25,16

Ex 25,21

Ex 25,26

Ex 25,30

Ex 26,32

Ex 26,33

Ex 26,34

?

Ex 28,23

Ex 29,3

Ex 28,30

Ex 29,6

Ex 29,17

Ex $30,16 ?$

Ex 30,18 bis

Ex 40,7 bis

Ex 40,8

Lv 2,15

Lv 24,7

Jg 15,18

1 R 3,9

1 R 8,39

$1 \mathrm{R} 8,34$

Ps 61,6

Dn 10,12

$\mathrm{Ne} 9,15$

$\mathrm{Ne} 9,35$ bis

Ne 9,20

Le siman ונתת את הטבעות a été corrigé; הטבעות a été barré et une autre main a écrit au-dessus הכפורת, qui renvoie à $\operatorname{Ex} 25,21$.

b. Hayyim, ת (31); Ginsburg, nun $\S 464$; Weil, Mm 657; Breuer, 224225.

\section{$\S 67$ (f. 75r)}

5 pִ au début du קחו ה רא פסו verset et leurs repères וסימ

Ex 35,5 Jos 4,2 ?

\begin{tabular}{|c|c|c|}
\hline פרעה & $\begin{array}{l}\text { Os } 14,3 \\
\operatorname{Pr} 8,10\end{array}$ & קחו מוסמם דברים ואסף \\
\hline ונתת התת את הטבעות השלחן & $\begin{array}{l}\text { b. Hayyim, לק (15); Gin } \\
\text { § 384; Weil, Mm } 3588 .\end{array}$ & ourg, lamed \\
\hline 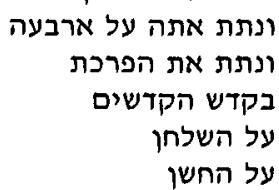 & $\begin{array}{l}4 \text { ו ולקְח dans le } \\
\text { Pentateuque et } \\
\text { leurs repères }\end{array}$ & ולקחתם ד בתו \\
\hline האול אורים & $\begin{array}{l}\text { Gn } 44 \\
\text { Ex } 12, \\
\text { Nb } 13 \\
\text { Lv } 23,\end{array}$ & 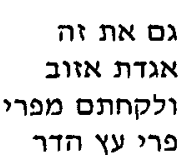 \\
\hline ג' & $\S 69$ (f. $75 r$ ) & urg, lamed \\
\hline על המערכת & 8 לקֵ et leurs repères & לקַח ח וסימ \\
\hline ונות ונת לעבדך & $\begin{array}{l}\text { Gn } 27,46 \\
\text { Dt } 27,25 \\
2 \text { R } 2,3 \\
2 \text { R } 2,5 \\
\text { Ez } 24,16 \\
\text { Ez } 37,19 \\
\text { Ez } 37,21 \\
\text { Pr } 9,7\end{array}$ & 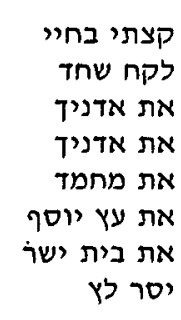 \\
\hline & $\operatorname{Pr} 11,30$ & \\
\hline
\end{tabular}

b. Hayyim, (2); Ginsburg, lamed § 393; Weil, Mm 201; Breuer, 164.

\section{$\$ 70$ (f. 75 r)}

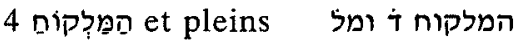

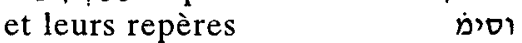

Nb 31,11 וסיקחק את כל השלל

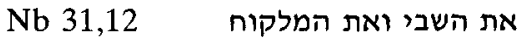
וחצית את המלקוח

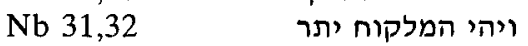

b. Hayyim, לק (14); Ginsburg, mem $\S 514$. 
$\S 71$ (f. $75 r$ )

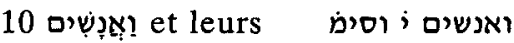
repères

$\mathrm{Nb} 16,2$

Jg 9,13

$1 \mathrm{~S} 22,6$

$1 \mathrm{R} 11,17$

Jr 26,22

$\mathrm{Ez} 23,45$

Qo 9,14

Ne 1,2

$\mathrm{Ne} 2,12$ $\S$ 925; Weil, Mm 2882.

\section{$\S 72$ (f. 76r)}

3 écrits hé et leurs repères

Gn 46,4

$\mathrm{Nb} 13,30$

2 S 15,30

b. Hayyim, על (55); Ginsburg, 'ain 547; Weil, Mm 341; Breuer, 253.

$\S 73$ (f. 76r)

3 [mots] défectifs והעלתם ג הסיס dans le lashon 'faire monter' et leurs repères

בליש וסלת גוסי

Gn 50,25

Ez 37,6

Mi 6,4

וישבע יוסף עליכם

כי העלתיך מארץ מצרים בערים

]et leur siman araméen]

Ginsburg, 'ain 579.

\section{$\S 74$ (f. 76v)}

3 ת על écrits comme cela et leurs repères

עלות ג כתי כן

Gn 41,3
Gn 41,5

Gn 41,19

ויישן ויחלם

et dans le reste du ושאר אורi עלת מלת כודת Pentateuque on écrit עתיذ על מול עולת sauf un écrit עולית

De 27,6 אבנים שלמות

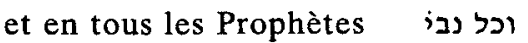

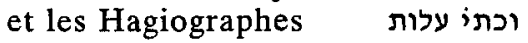

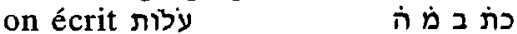

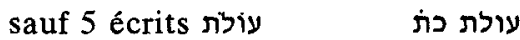
et leurs repères וסימ

Ez 45,17

Mi 6,6

Ps 58,3

Ps 64,7

ועל הנשיא יהיה

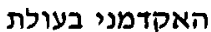
אף באקדב עולת בעולת יחפשו עולת כל בעלת

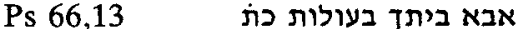

b. Hayyim, על (62 et 66); Ginsburg, ain 569-572 et 204-205; Weil, Mm 297.

\section{$\S 75$ (f. 76v)}

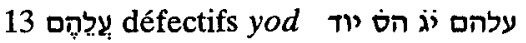

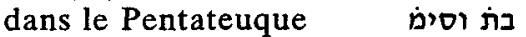
et leurs repères

Gn 45,15

Gn 47,20

Ex 5,14

Ex 9,19

Ex 15,19

Ex 16,20

Ex 18,21

Ex 32,34

Lv 4,20

$\mathrm{Nb} 4,27$

$\mathrm{Nb} 7,9$

Nb 11,26

וינשק לכל אחיו ויקן יוסק לכל אטי ויכו שטרי יוסף וירד עלהם הברד כי בא סוס פרעה תלרד וירם תולעים סוס פרעים ואתה תחזה ויעים וביום פקדי וארי ועשה לפר על פי אהרן לפר וער ולבני קהת לא נתן וישארו שני אנשים לאנת ולתים ועננך עמד עלהם שנים $\mathrm{Nb} 14,14$

b. Hayyim, על (27); Ginsburg, 'ain § 536; Weil, Mm 675; Breuer, 384 385 . 


\section{$\S 76$ (f. 77r)}

9 לאמו au début du verset et leurs repères לאמר ט רסיא פסו וסמר טימ

לאמר שובו נא איש מדרכו הרעה Jo 25,5 Is 49,9

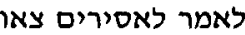

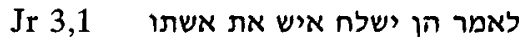

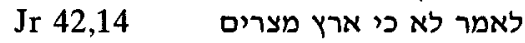
1 Ch $16,18 \quad$ Ps 105,11

וחברור לאי לאיר

לאמר אל הכהנים אשר בבית "

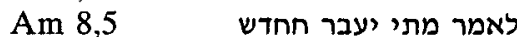
לאמר אלהים עזבו יעבר

b. Hayyim, אם (60); Ginsburg, alef $\S$ 826; Weil, Mm 3072; Cairo, Is 49,9 et Am 8,5.

\section{$\S 77$ (f. 78r)}

3 לאמוiר pleins et leurs repères

Gn 48,20

Jr 18,5

Jr 33,19

הכיוצר הזה Jr 18,6, de même que אם תפר se trouve en Jr 33,20. Les versets Jr 18,5 et 33,19 se ressemblent tellement qu'on a été obligé de citer le verset suivant pour les distinguer.

b. Hayyim, אמ (64); Ginsburg, alef \& 827; Weil, Mm 358; Breuer, 263.

\section{$\S 78$ (f. 78r)}

6 אמוֹ 3 pleins et 3 défectifs et leurs repères

$\mathrm{Nb} 6,23$

1 S 2,30

Jr 23,17

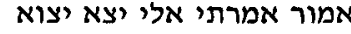

et 3 défectifs

אומרים אמור למנאי אי יצי

Ex 21,5

וג ח
אמר אמרתי כי שנא שנאתה $1 S$ אם אמר אמר לנער הנה החצי

b. Hayyim, אם (37); Ginsburg, alef $\S 824$; Weil, Mm 873 et 1487 ; Cairo, Jr 23,17 et $1 \mathrm{~S} 20,21$; Breuer, 352 et 568; Ognibeni, §§ 9 F-G.

\section{$\S 79$ (f. 78r)}

ואומר ג מל וסימנהון pleins ואוֹמר 3 et leurs repères

ואומר למלך אם על המלך טוב 2,5 ואם "יטר למלך

ואומר אלהם אתם ראם ראים הרעה ואשיב אותם דבר ואומר להם Ne 2,20 et tous en Esdras- וכלהון בעזרא Néhémie

b. Hayyim, אמ (52); Ginsburg, alef $\S 886$.

\section{$\S 80$ (f. 78v)}

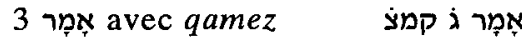
et leurs repères ואימנ

Gn 18,17

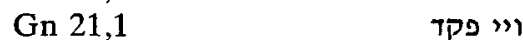

Ex וישמע משה לקול חתנו

b. Hayyim, אם (42); Ginsburg, alef $\S 803$; Weil, Mm 135; Breuer, 112; Ognibeni, § 193.

\section{$\S 81$ (f. $78 v$ )}

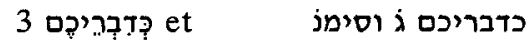
leurs repères

גם עת נדבריכם

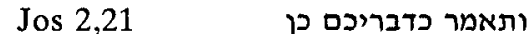

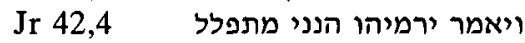

b. Hayyim, דב (34); Ginsburg, dalet $\S 109$; Weil, Mm 2694; Löwinger, Jr $\S 307$; Cairo, Jr 42,4; Breuer, 245. 
$\S 82$ (f. $78 v)$

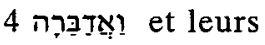
repères

Gn 18,30

Dt 32,1

Ps 40,6

Ps 50,7
Gn 40,14

Ex 12,48

Lv 19,13

Ex 17,5

אל נא יחר קדפ

האזינו השמים יחר ימד אין ערוך אליד המים שמעה ואדברה עליד

b. Hayyim, דב (44); Ginsburg, dalet $\S 73$; Weil, Mm 1232; Löwinger, Ps § 76; Breuer, 115.

\section{$\S 83$ (f. 78v) \\ 4 הַמְדבּבּר repères}

Gn 45,12

2 S 14,10

Is 52,6

Dn 8,13

המדבר ד וסימ

Ex 25,22

Ex 34,27

Lv 19,33

Nb 18,7

$\mathrm{Nb} 18,11$

Nb 18,19

Dt 10,21

Dt 28,8

עיניכם ראוק אליכו

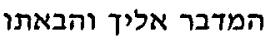
כי אני הוא המדבר לפלמני המדבר חוא המדר
כי אם זכרתני וכי יגור אתד גר זכרת ולא תלין פעלת מתור גור וקח אתך מזקני פעלת

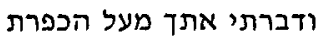
כרתי אתך ברית אתך וכי יגור גר אתר ברי כרי תשמרו את בהנת נרכם וזה לך תרומת מתנס כתנם נתום כל תרומת הקדשים הוא תהלתך תרומת יקד יצו " אתך תחלך

Il faut corriger la rubrique, y insérant la précision "dans le Pentateuque", qui est tombée.

b. Hayyim, (54); Ginsburg, alef $\S$ 1449; III, 219; Weil, Mm 60 et 940; Breuer, 86-87.

b. Hayyim, דב (20); Ginsburg, dalet § 76; Weil, Mm 333.

\section{$\S 84$ (f. 79r)}

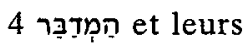
repères

Gn 45,12

2 S 14,10

Gn 45,12

2 S 14,10

Dn 8,13

C'est une autre rédaction, corrompue, de la liste précédente.

\section{$\S 85$ (f. $78 v$ )}

14 אִּุ [dans le Pentateuque] et leurs repères

Gn 8,17

Gn 26,24

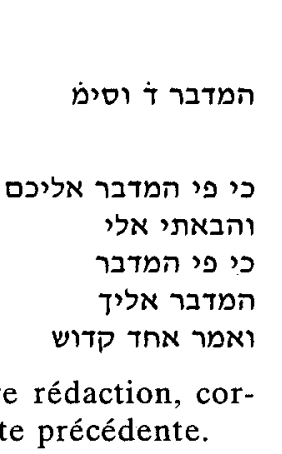

אְִּּך זֹד וסימ

כל החיה אשר אתך כי אתך אני וברכתיד אתר

\section{§ 86 (f. 79r)}

ודבריו ה וסימנהון repères

Dt 4,36

2 Ch 35,27

2 Ch 13,22

Qo 9,16

Jb 34,35

ודבריו שמעת הראשנים והאחרנים ודבים אביה דדברי הימים והתרנים אינם נשמעים דוברים איוב לא בדעת ידמם ידר

b. Hayyim, דב (22); Ginsburg, dalet $\$ 107$; III, 253; Weil, Mm 1077; Löwinger, Ch § 297.

\section{$\S 87$ (f. 79v)}

ויצום דֹ וסימנחון repères

Ex 6,13

Ex 34,32

2 R 11,5

2 R 17,35

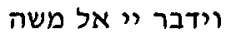

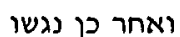

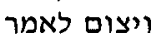
ויכרות ויצום

b. Hayyim, ו (22); Ginsburg, zadé § 99; Weil, Mm 409. 


\section{$\S 88$ (f. 79r) \\ Toute la racine écoute [est suivie עַל 12 אַ 12 sauf et leurs repères}

\begin{tabular}{|c|c|}
\hline Gn 41,15 & ואני שמעתי עליך \\
\hline Is 37,9 & וישמע על תרחקה \\
\hline$?$ & ומלכים דרשו \\
\hline $\operatorname{Jr} 4,16$ & הזכירו \\
\hline Jr 6,7 & כהקיר בור כת \\
\hline Jr 23,16 & אל תשמעו \\
\hline Jr 26,5 & לשמע \\
\hline$?$ & אל הרכבים \\
\hline Jr 35,18 & ולבית הרכבים \\
\hline Jr 4,6 & שאו נס ציונה \\
\hline Ez 27,30 & בקולם \\
\hline Am 3,9 & השמיעו על ארמנות \\
\hline Ne 9,9 & ואת זעקתם שמעת על ים סוף \\
\hline
\end{tabular}

$\S 89$ (f. 79r)

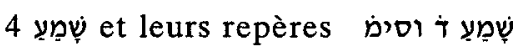

ויגד להם מיכיהו את כל הדברים Jr 36,13 Ps 34,7

Ps 34,18

Ps 22,25

et leur siman [en langue araméenne]

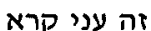

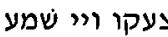
ובשועו אליו שמעו שמע

וסימ פתגמיא ובעוע דמסכינא צוחתמא וסיוא וצלותא נומסינא

b. Hayyim, שמ (99); Ginsburg, shin $\S 716$; Weil, Mm 2671; Löwinger, Jr § 266; Cairo, Jr 36,13.

$\S 90$ (f. 79v)

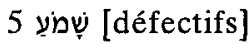
et leurs repères

Ex 22,22

Dt 1,16

Dt 11,13

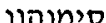

שמע אשמע צעקתו
$1 \mathrm{~S} 23,10$

שמע שמע עבדך נהיה אם שמע תשמעו אל b. Hayyim, שמ (91); Ginsburg, shin § 721; Weil, Mm 1115; Breuer, 357.

\section{$\S 91$ (f. 79v)}

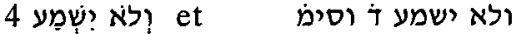
leurs repères

Ex 7,4

Dt 21,18

Jos 1,18

Is 42,20

ולא ישמע אלכם פרעה ולמע ויסרו אתו ולא ישמע יכל יער כל איש אשר ימרה ולאי ומשע פקוח אזנים ולא ישמר ימרע

b. Hayyim, שמ (81); Ginsburg, lamed $\S 247$; Weil, Mm 1179; Löwinger, Jos $\S 7$; Cairo, Is 42,20.

\section{$\S 92$ (f. 79v)}

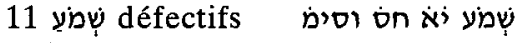
et leurs repères

Nb 30,9

Dt 17,12

1 S 15,22

Is 28,12

Is 30,9

Jr 16,12

Jr 17,23

Jr 18,10

Jr 19,15

Jr 42,13

Dn 9,11

ואם ביום שמע והאיש אשר יעשה במדודון הנה שמע מזבח וה יעשה

לא אבו שמע תורתי מעי מעי כי עם מרי הוא שמע תוא

ואתם הרעתם לעשות מרות ויקשו את ערפם וערס לעשי ועשו הרע בעיני איפס כי הקשו את ערוע בעיני איפם

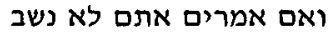
וסור לבלתי שמע בקים לאולך les derniers pleins בתר מלאi

L'adjectif 'défectifs' dans la rubrique porte à faux. Cette liste regroupe en effet les onze עִ שุ construits sans égard pour la graphie défective ou pleine.

b. Hayyim, שמ (94); Ginsburg, shin \$ 722; Weil, Mm 2550; Cairo, Is 28,12. 
$\S 93$ (f. 79v)

7 et leurs repères

Gn 6,14

Nb 10,2

Nb 21,8

Jos 5,2

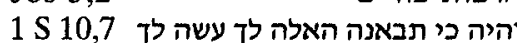

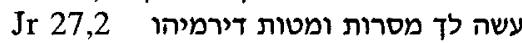

בן ארם עשה לך כלי גולה

b. Hayyim, עש (29); Ginsburg, 'ain $\S 834$; Breuer, 577.

\section{$\S 94$ (f. 79v)}

4 עשה ד וסיט 4 et leurs repères

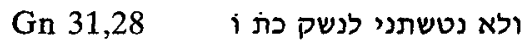

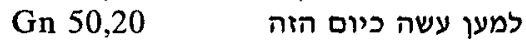

Pr 21,3

Ps 101,3 עשה צדקה ומשפט כשוס עיה עשה שטים שנאתי עמשת

3 écrits avec hé ג ג

b. Hayyim, ע (22); Ginsburg, 'ain $\S$ 823; Weil, Mm 3631; Breuer, 183.

\section{$\S 95$ (f. 79v)}

עשתה ה וסימ et leurs repères

Gn 27,17

2 S 13,10

Is 66,2

Est 2,1

Est 5,12

ותתן את הלחם ואת הלבבות התות הת עת

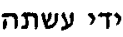

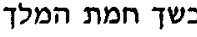
אף לא הביאה חמלת

b. Hayyim, ע (41); Ginsburg, ain § 813; Weil, Mm 197; Breuer, 160.

\section{$\S 96$ (f. 80r)}

5 עִ et leurs repères

Gn 3,13

Jr 2,23

Rt 2,19

Rt 2,11

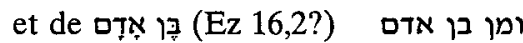

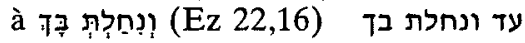
comme eux רכות ונחלת בד (Ez 22,16)

b. Hayyim, שy (35); Ginsburg, ain 816; Breuer, 61.

\section{$\S 97$ (f. 80r)}

un seul עִשִׁ丨ִ

עשיתה ל

וידעו כי ידך זאת אתה יהוה Ps 109,27

\section{$\S 98$ (f. 80r)}

[Après une forme עשיה הדבר יא

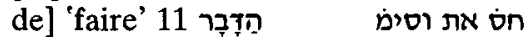
sans et leurs repères

Gn 19,22 מהר המלט שמה

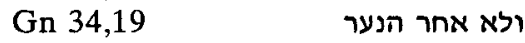

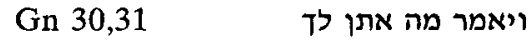

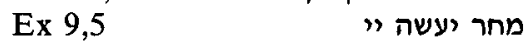

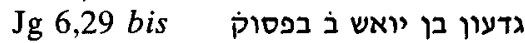

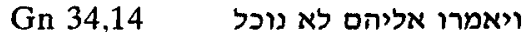
לעשות הדבר אליחם

Ex 1,18 ויקרא מלך מצרים למילדות 2 S 2,6

Jg 11,37 וגם אנכי אעשה מצרים יעשה לי וגכי יעדי

2 R 8,13 כי מה עבדך הכלב ל

b. Hayyim, עש (31); Ginsburg, ain $\S 805$; Breuer, 120.

\section{$\S 99$ (f. 80r)}

ולא עשו ה וסימ repères

Ex 1,17

Jg 8,35

2 R 18,12

Jr 11,8

2 Ch 21,19

כאשר דבר אלהן חסד עשר בית אלח ירובעל על אשר לא שמעו בית שורעל ולא שמעו אשר ליאו ולא עשו לו שרפה שמו ולאה

Weil, $\mathrm{Mm}$ 2512; Löwinger, $\mathrm{Ch} \S$ 351; Cairo, Jg 8,35; 2 R 18,12; Jr 11,8 . 


\section{$\S 100$ (f. 80v)}

13 לַעִ défectifs et leurs repères

Ex 35,1

Ex 35,32

Ex 36,1

Ex 36,2

Ex 36,3

Ex 36,5

Lv 8,34

$\mathrm{Nb} 9,4$

Nb 9,6

Esd 7,10

$\mathrm{Ne} 8,15$

Ne 12,27

Ne 13,27

b. Hayyim, ע (36); Ginsburg, 'ain $\S 825$; Breuer, 409.

\section{$\S 101$ (f. 80v)}

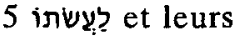
repères

Ex 12,48

Gn 41,32

Dt 30,14

Jr 1,12

$2 \mathrm{Ch} 30,3$

b. Hayyim, עy (45); Ginsburg, 'ain \$ 831; Weil, Mm 305; Breuer, 229 230 et 757 .

\section{§ 102 (f. 81r)}

2 מַעִ défectifs dans le Pentateuque et leurs repères

מעשות ב חס מסוס בתו וסימ מעומ

Gn 18,25

Lv 9,22

חלילה לך וירד מעשת החטאת לות

Ginsburg, 'ain § 827; Weil, Mm 711.

\section{$\$ 103$ (f. 81r)}

יום liés et leurs repères

Gn 39,10 ויהי כדברה אל יוסף והיה משנה על אשר ילקטו

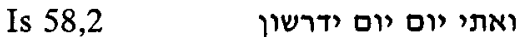
לשלמי נדרי יוס יוס ודרשון ברוך " יום יום יום יום שעשועים יום יום יום יום לשקד על דלתותי יום יום

b. Hayyim, " (19); Ginsburg, yod $\S$ 224; Weil, Mm 484; Cairo, Is 58,2; Breuer, 220-221.

\section{$\$ 104$ (f. 81v)}

בימים דֹ וסימ 4 בְּיְמִים

Dt 1,46

Dt 10,10

Zc 8,11

Est 9,22

אשר ישבתם עמדתי ואנכי עמדתי בשתחם לשארית העם ואניתי בעי ניחו כימים אשר נחו העם

b. Hayyim, " (31); Ginsburg, yod $\S$ 255; III, 248; Weil, Mm 3162; Breuer, 673.

\section{\$105 (f. 81v)}

2 לุ่ défectifs

לטבה ذ חס du livre [= le Penta- דס וסימ נס ל teuque] et leurs repères

Gn 50,20 אלהים חשבה לטבה

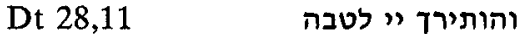

b. Hayyim, ב (24); Ginsburg, tet $\S 51$; Weil, Mm 1222; Breuer, 270 et 757 .

\section{$\S 106$ (f. 82r)}

[Dans le lashon] faire du bien' 8 [mots] défec- חס וסימ tifs et leurs repères 
Dt 8,16

Dt 30,5

1 S 20,13

$1 \mathrm{~S} 25,31$

Jr 2,33

Ez 33,32

Ez 36,11

Pr 15,13

Pr 30,29

tous défectifs du second yod sauf un défectif et défectif

Ez 33,32

$1 \mathrm{~S} 16,17$

plein et plein

מִטִיב et le reste des et וּמֵטִיב défectifs du premier yod

יפה קול ומטב נגן

מיטיב לנגן

מלא דמלא לנגו

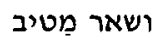

ומטיב חס מטיב

קדמא ומטיב

b. Hayyim, טב (18); Ginsburg, yod $\S$ 298; III, 257; Weil Mm 1098; Breuer, 697.

\section{$\S 107$ (f. 83r)}

2 לָָח et leurs repères

Ex 16,22

$\mathrm{Nb} 15,12$

שני העמר לקור

ככה תעשו לאחור הער

b. Hayyim, Nb 15,12; Ginsburg, alef $\S 280$; Breuer, 599.

\section{$\S 108$ (f. 83v)}

"ין ; בלי וסימ dans le lashon et leurs repères

Dt 32,38

Ez 27,18

Am 2,8

$\operatorname{Pr} 4,17$

Os 14,8

Ct 7,10 ויין חמסים ישתו ליום ינויו זכרו כיין לבנון וחכך כיין הטוב לניון
Est 1,7

Dn 1,16

Dn 1,5

Dn 1,8

ויין מלכות רב

ויין משתיהם מלכות רביון

ומיין משתיו משתים

בפתבג ומיו מש

b. Hayyim, " (1); Ginsburg, yod $\S$ 307.

\section{$\S 109$ (f. 83v)}

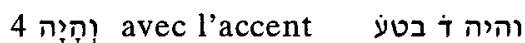
[gershayim] et leurs וסימ repères

Ex 12,25

Ex 13,11

Ex 13,14

Ex 18,22

והיה כי תבאו

והיה כי יביאך כיהו כיה

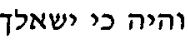
והיה כל הדבר כיר

b. Hayyim, (48); Ginsburg, hé $\S$ 125.

\section{$\S 110$ (f. 84r)}

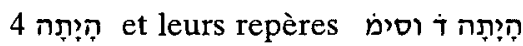
אם לא כאשר דמיתי כן היתה 14,24 2 Ch 15,19

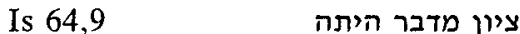
על כן לנידה היתה

b. Hayyim, ה (17); Ginsburg, hé $\$$ 137; Weil, Mm 3721; Löwinger, Is $\S 76$; Cairo, Is 14,24 et 64,9 .

\section{$\S 111$ (f. 84r)}

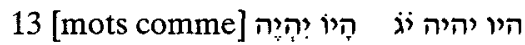
avec accents différents בטע מתחלפ et leurs repères

Gn 18,18

Lv 7,33

Ex 21,35

Jos 8,9

"Jos 8,12 ויין ענושים חלבון ישתו
וכל אשר אין לו דמשנה תורה 14,10 וכרו

2 S 20,6

1 S 30,17

Qo 9,10

2 S 17,17
ואברהם היו יהיה לו תהיה שוסה היוק ביכי יגף שור איש שיש בין ביתאל ופרי עתה ירע לנו ארו לו אוכנ ארבע מאות איש נער נער יער כל אשר תמצא ידך יואי נער כי לא יוכלו 
Os 10,14

1 R 22,34

mais on est divisé au sujet de ce siman

יהפד ידן שלמן דמלכים

Cette liste groupe douze combi-

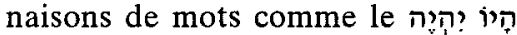
de Gn 18,18, dont le premier a l'accent darga et le second l'accent tevir. Le tevir étant normalement précédé par le merka, c'est le darga qui fait exception.

Dans son commentaire à tet § $180 \mathrm{~b}$ (liste omise dans l'édition), Ginsburg interprète ainsi la notice finale de cette liste: "the textual redactors are divided in their opinion whether it is the passage in 1 Kings 22,34 or 2 Chron 18,33 which has the Darga".

Frensdorff, § 221; Ginsburg, tet $\S$ $180 \mathrm{~b}$.

\section{$\S 112$ (f. 84v)}

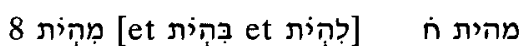

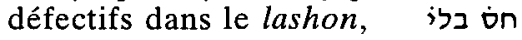
et leurs repères

Ex 9,28

Ex 19,16

Ex 23,1

Ex 36,18

Ex 39,21

Ex 40,15

Lv 26,13

להית על חשב האפדוד

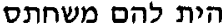

מהית להם עבדים משתם

b. Hayyim, in (21); Ginsburg, hé $\S$ 152; Weil, Mm 725; Breuer, 344.

\section{$\S 113$ (f. 84v)}

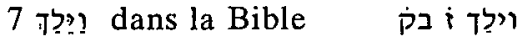
avec patah et leurs repères

Gn 24,61
Gn 25,34
Nb 12,9

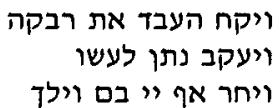

1 S 21,1

2 R 5,11

Ps 34,1

Jb 7,9 $\S 363$; Weil, Mm 175; Cairo, 1 S 21,1; Löwinger, Ps $\S 53$; Breuer, 147-148; Ognibeni, § 326.

\section{$\S 114$ (f. 84v)}

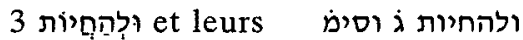
repères

Gn 45,7

2 R 5,7

Is 57,15 האלהים אני להמית אלחים ולהחיות לב נדכאים לחמים

b. Hayyim, 'n (22); Ginsburg, het § 193; Weil, Mm 2068; Cairo, Is 57,15; Breuer, 249.

\section{$\S 115$ (f. 85v)}

9 אַwe et leurs repères

אשלח ט וסימ

Gn 38,17

Ex 10,10

Ex 23,27

Dt 32,24

Ez 5,16

Ez 14,19

2 Ch 7,13

b. Hayyim, ש (14); Ginsburg, shin $\S 528$; Weil, Mm 425; Löwinger, Aleppo p. 99 et Ez $\S 31$; Cairo, $1 \mathrm{R}$ 9,7; Ez 5,16; Breuer, 217 et 299.

\section{$\S 116$ (f. 85v)}

3 שָׁלוּחָה

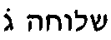

2 pleins et un défectif et leurs repères

וסימ

Gn 32,19

Gn 49,21

מנחה היא שלוחה

Ez 2,9

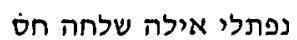

והנה יד שלוחה אלי שלחי 
b. Hayyim, של (20); Ginsburg, shin § 511; Weil, Mm 240; Löwinger, Ez $\S 15$; Cairo, Ez 2,9; Breuer, 193.

\section{$\$ 117$ (f. 86r)}

7 שלחה ז וסימ

Gn 43,8

$1 \mathrm{~S} 16,11$

1 S 16,19

2 R 4,22

Ez 17,7

Ez 31,4

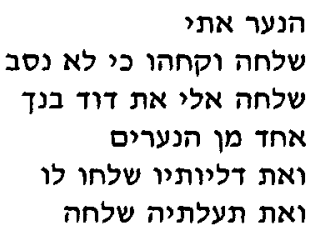

b. Hayyim, (17); Ginsburg, shin $\S$ 499; Weil, Mm 2915.

\section{$\S 118$ (f. 86r)}

5 שלום שלום ה וסימ et leurs repères

Is 26,3 Iיר סמוך תצר שלום שלום

Is 57,19

Jr 8,11

Jr 6,14

בורא ניב שפתים שצרים שפרים וירפו את שבר שפתים וירפאו את שבר שת שת את וירפו

1 Ch 12,19 ורוח לבשה את עמשרי

b. Hayyim, של (46); Ginsburg, shin $\S 453$.

\section{$\S 119$ (f. 86r)}

8 שִׁ défectifs dans le lashon, et leurs repères

Gn 37,4

$1 \mathrm{~S} 16,4$

1 R 2,6

$1 \mathrm{R} 2,5$

1 R 5,26

Jr 15,5

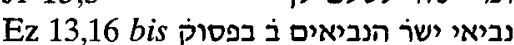

b. Hayyim, של (40); Ginsburg, shin § 451; Weil, Mm 1614; Breuer, 209.

לשלום ח בליט וסיט

ולא יכלו דברו

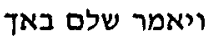
ולא תורד שיבתו בשלם שאול משל מאול וישם דמי מלחמה בשלם תים שלים

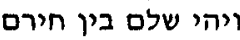

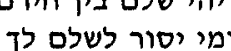

$\S 120$ (f. 87r)

un seul ?בון

ירבון ל

Ps 139,18

אספרם מחול

$\S 121$ (f. 87r)

כל לשון ברכים 'Tout le lashon 'genoux'

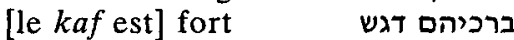
sauf 2 faibles

Jg 7,6

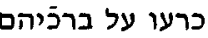

Dn 6,11 הוא ברך על ברכוהי בכיהי

Cette liste regroupe les deux .seules formes de rafé.

b. Hayyim, Dn 6,11; Ginsburg, bet $\S 508$; Weil, Mm 1435.

\section{$\$ 122$ (f. 87r)}

דל יj פתח בלי וס; נד 12 avec patah dans le lashon, et leurs repères

Ex 30,15

Lv 14,21

Jg 6,15

2 S 13,4

Is 17,4

Ps 141,3

Jb 5,16 Jb 28,4

$\mathrm{Jg} 6,6$

$\operatorname{Pr} 28,11$

העשיר לא ירבה

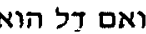

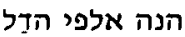
מדוע אתה ככה דל הכל כלי כלד

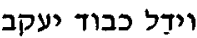

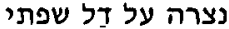

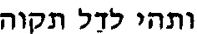

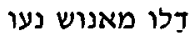
וּידל ישראל מאנוש נעו

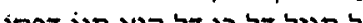
אם דל ואם עשיר

וכל דַל ואביון

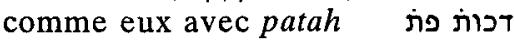

b. Hayyim, לד (1); Ginsburg, dalet $\S 163$.

$\S 123$ (f. 87v)

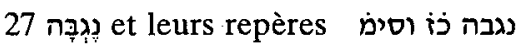




\begin{tabular}{|c|c|c|c|}
\hline Gn 13,14 & ויי אמר אל אברם & Ps 61,7 & ימים על ימי מלך \\
\hline Gn 28,14 & והיה זערך כעפר & Jb 20,9 & עין שזפתו ולא תוסיף \\
\hline Ex 26,18 & ועשית את הקרשים למשכן & $\mathrm{Jb} 38,11$ & ואמר עד פה תבא \\
\hline $\mathrm{Ex} 40,22$ & ויתן את & Pr 10,27 & "ראת " תוסיף חכמה \\
\hline Jos 15,1 & אל גבול אדום & $\operatorname{Pr} 19,19$ & גדל המה \\
\hline Jos 15,2 & מן הלשון & $\operatorname{Pr} 23,28$ & אף היא כחתף \\
\hline Jos 18,21 & והיו הערים & \multirow{3}{*}{\multicolumn{2}{|c|}{$\begin{array}{l}\text { b. Hayyim, o' (27); Ginsburg, yod } \\
\S 430 \text {. }\end{array}$}} \\
\hline Jos 17,9 & וירד הגבול & & \\
\hline Jos 17,10 & לאפרים & & \\
\hline Jos 18,13 & ועבר משס & \multirow{2}{*}{\multicolumn{2}{|c|}{$\S 125$ (f. 88r) }} \\
\hline Jos $18,14 b i$ & ותאר ذ בו & & \\
\hline Jos 18,15 & ופאת & 5 צִ צִקסת et leurs & צדקת ה וסימנהון \\
\hline Jos 18,16 & וירד & repères & \\
\hline Jos 18,19 & ועבר & Dt 33,21 & וירא ראשית לו \\
\hline 1 R 7,25 & עמך & $\mathrm{Ez} 18,20$ & צדקת הצדיק \\
\hline Ez 47,19 & מריבות & Ez 33,12 & וחברו \\
\hline Ez 48,10 & ולאלה & $\operatorname{Pr} 11,5$ & צדקת תמים תישר \\
\hline $\begin{array}{l}\text { Ez } 48,17 \\
\text { Ez } 48,33\end{array}$ & והיה מגרש & $\operatorname{Pr} 11,6$ & ישרים תצילים \\
\hline $\begin{array}{l}\text { EZ } 48,33 \\
\text { Zc } 14,4\end{array}$ & וחצאיו רא 102 & et un [ונצִדקתת]] & וחד - - - (חד \\
\hline 1 Ch 9,24 & לארבע & Is 5 , & וצדקת צדיקים \\
\hline $1 \mathrm{Ch} 26,15$ & לעבד & & \\
\hline 1 Ch 26,17 & לנגבה ליום & \multirow{4}{*}{\multicolumn{2}{|c|}{$\begin{array}{l}\text { b. Hayyim, Tצ (5); Ginsburg, zadé } \\
\S 61 \text {; Weil, Mm } 1242 ; \text { Cairo, Ez } \\
18,20 \text { et } 33,12 \text {; Löwinger, Aleppo } \\
104 \text { et } \operatorname{Pr} \S 48 ; \text { Breuer, } 770 \text {; Ogni- }\end{array}$}} \\
\hline $2 \mathrm{Ch} 4,4$ & עמד & & \\
\hline $2 \mathrm{Ch} 4,10$ & ואת הים נתן & & \\
\hline Dn 8,4 & את האיל & & \\
\hline
\end{tabular}
rrences de que précédé de la conjonction waw ou des prépositions bet et lamed (mais non de l'article).

b. Hayyim, ג (1); Ginsburg, nun $\S$ 73.

\section{$\S 124$ (f. 88r)}

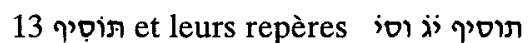

Ex 11,6

Dt 28,68

Is 24,20

Ez 36,12

Am 5,2

Am 7,13

$1 \mathrm{Ch} 22,14$

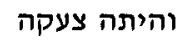
והשיבך " מצתרים מעת מחים נוע תנוע והער והולכתי נפנועי נפלה וחלת ובית ובית אל נפלה הכינותי וביתי

\section{$\S 126$ (f. 88v)}

8 הפדרוֹ pleins dans le Pentateuque et leurs repères

$$
\begin{array}{r}
\text { הגדול ח מל } \\
\text { הסימנה }
\end{array}
$$

Gn 10,21

Lv 21,10

$\mathrm{Nb} 34,6$

Dt 1,19

Dt 4,32

Dt 4,6

Dt 29,23

Dt 34,12

ולשם ילד גם הוא מאגו

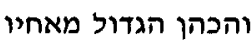
וגבול ים הים הגדול מאחול מנלי ונסע מחרב ונלך חיר חניד הנחיה כדבר הגדול ונדול

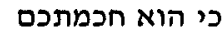
מה חרי האף הגדול חמתפס הכדי ולכל היד החזקה הגדול הוקה

b. Hayyim, גד (6); Ginsburg, gimel $\S 64 ;$ Weil, Mm 73; Breuer, 49 et 92. 
$\S 127$ (f. 89r)

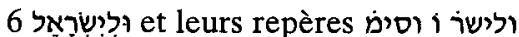

Ex 18,1

Ex 32,13

$\mathrm{Nb} 23,23$

$1 \mathrm{R} 8,66$

2 Ch 7,10

Mi 3,8

וישמע יתרו

זכר לאברהם וליצחק

בעת יאמר לאברת

ביום השמיני שלח את העם

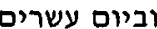

להגיד ליעקב פשרום

b. Hayyim, שי (67); Ginsburg, yod $\S$ 739; Weil, Mm 967; Löwinger, Ch $\S 261$; Cairo, Mi 3,8; Breuer, $337-338$ et 397 et 627 .

\section{$\S 128$ (f. 89r)}

33 וְי? 3 et leurs repères

Gn 37,3

$\mathrm{Nb} 24,18$

Is 42,24

1 S 17,3

1 S 29,1

1 R 4,20

2 S 19,9

1 R 5,5

1 R 18,36

Jr 10,16

Jr 23,6

Is 43,28

Is 44,1

Is 44,21 bis

Is 45,4

Is 49,5

Is 48,12

Is 63,16

Os 5,3

Os 5,5

Am 7,17?

1 Ch 1,34

1 Ch 29,18

2 Ch 16,11

2 Ch 25,26

2 Ch 28,26

2 Ch 32,32

2 Ch 30,6 עשה חיל את ליל וישר לבוזזים עומדים אל ההר לבוזים חנים בעץ עיד יהודה וישר בעי ליר

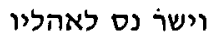
וישב יהודה וישל נהלי וישר ויהי בעלות יואב יחודב שבט נחלתו בעלות יהואי ניחו

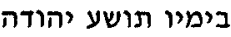
וישר לגדופים תושעים ועתה שמע לגדופים

זמור אלה יעקב ב בוע למען עבדי יעקב יעקב לי יאסף עמרי

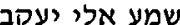
כי אתה אבינו יעדי

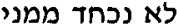
וישר ואפרים יכמניו ואלו

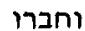
בני יצחק שמרה זאת יצחק אסא שמרה אמציהו אחי אמצותו יחוקיהו שובו אל "יחו אלהי אברהם
2 Ch 35,18

Ps 81,12

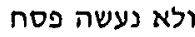
ולא שמע עמי לקולי נעשי

Le siman וחבר après Os 5,5 n'a pas de sens: il faut supposer que Am 7,11 soit tombé accidentellement de la liste, et que "son compagnon' soit par conséquent Am 7,17. Voir infra, § 188.

b. Hayyim, w' (52); Ginsburg, yod $\S 738$; Löwinger, Ch $\S 1$; Breuer, 209-210.

\section{$\S 129$ (f. 89r)}

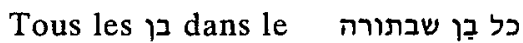

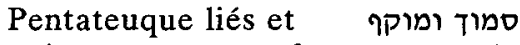

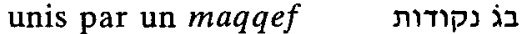
avec 3 points [= segol], sauf un

Gn 30,19 בֵן ששי ליעקב et tous les וכל בן בער accentués et séparés בטעם ונרש בטרש avec deux points [=zéré] בשתי נקודות וגרות sauf 2 , et leurs repères Lv 1,5 וישחט את בֶן הבקר

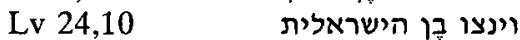
Ginsburg, bet $\S 334$ (voir commentaire).

\section{$\S 130$ (f. 89r)}

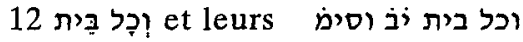
repères

Gn 50,8

וכל בית יוסף

Jg 9,6

Jg 16,31

וכל בית מלוא ביסף וכיר

1 S 22,1

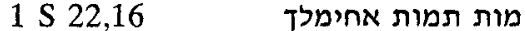

2 S 6,5

וכל בית ישראל משחקים משלים וכל בית ישר מעלים וכל בית שאן אשר מעלים וכל בית ישר ערילי לב אחר אחיך אחיך 
Ez 12,10

Ez 37,16 הנשיא המשא וכל בית ישראל חבריו

b. Hayyim, ' בי (23); Ginsburg, kaf § 235; Weil, Mm 1447; Cairo, Jg 16,31; 1 S 22,16; 2 S 6,15; 1 R 4,12; Ez 11,15.

\section{§ 131 (f. 89v)}

יראה יג וסימ et leurs repères ירֶֶה 13 Gn 22,14

Ex 13,7 bis

Ex 23,17

Ex 34,23

Dt 16,16 bis

Dt 16,4

$\mathrm{Jg} 5,8$

Is 60,2

Zc 9,14

Ps 84,8

Ps 90,16

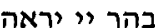

מצות יאכל ذ בפסוק שלש פעמים בשנה דהכא בפסקא וודכי תשא פעמם

ודראה אנכי ב בפסוק לך שאור ירור מגן אם יראה עור עלור יכור וכבודו עליך יראה יאה וראה ו"י עליהם יראלי ירה ירה

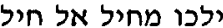
יראה אל עבדיך פעלך

b. Hayyim, ר (19); Ginsburg, resh § 68; Weil, Mm 150; Löwinger, Ps $\S$ 217; Cairo, Jg 5,8; Is 60,2; Zc 9,14; Breuer, 719.

\section{\$ 132 (f. 89v)}

ומראה זֹ וסימ et leurs repères ומַרֵאה 7

Ex 24,17

Lv 13,3

Lv 13,32

$\mathrm{Nb} 9,16$

Ez 10,9

Dn 1,13

Dn 8,26

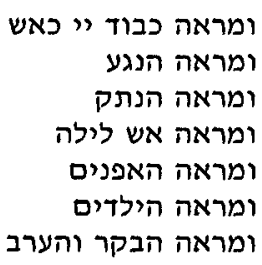

Une autre main a ajouté à la fin de la liste: וחד פתח וימַראה ולא

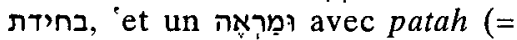
segol): ולא בחידת (Nb 12,8)'.

b. Hayyim, ר (37); Ginsburg, mem \& 752; Weil, Mm 539; Cairo, Ez 10,$9 ;$ Breuer, 477 et 576 .
$\S 133$ (f. 89v)

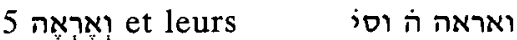
repères

Gn 18,21

Ex 4,18

Ex 3,3

Dt 3,25

1 S 20,29

ארדה נא ואראה

העודם חיים נארים

אסורה נא ואראה חיום אעברה נא נאורה נא איטוא אמלטה נארח נא

b. Hayyim, רา (9); Ginsburg, resh $\S$ 52; Weil, Mm 394; Cairo, 1 S 20,29; Breuer, 113.

\section{$\S 134$ (f. 89v)}

וראיתי ז' וסימ repères

Ex 12,13

1 S 19,3

Ez 37,8

Ez 41,8

Dn 10,7

Dn 12,5

Qo 2,13

Qo 3,22

Qo 4,4

Qo 8,17

Est 8,6 bis

b. Hayyim, רא (10); Ginsburg, resh $\S 25$; Weil, Mm 445; Cairo, $1 \mathrm{~S}$ 19,3; Ez 37,8 et 41,8; Breuer, 312.

\section{$\S 135$ (f. 89v)}

במראת דֹ וסימز repères

ויאמר אלהים לישראל במראת הצבאות Ez 8,3 בציצת ראשי הצנית

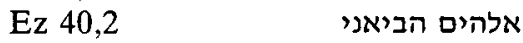

b. Hayyim, רא (4); Ginsburg, mem § 747; Weil, Mm 340; Cairo, Ez 8,3; Breuer, 252. 
§ 136 (f. 89v)

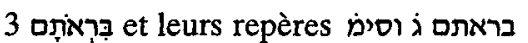

Ex 13,17

$1 \mathrm{~S} 17,24$

2 Ch 15,9

b. Hayyim, רא (31); Ginsburg, resh 40; Weil, Mm 459; Löwinger, Ch $\$$ 305; Cairo, 1 S 17,24; Breuer, 319.

§ 137 (f. 90r)

4 ירוּרוּ repères

ייראוך ד וסימ

$1 \mathrm{R} 8,40$

2 Ch 6,31

Is 25,3

Ps 72,5

ייראוך עם שמש עריצים b. Hayyim, ר (5); Ginsburg, yod § 568; Weil, Mm 1924; Cairo, Is 25,3.

$\S 138$ (f. 90r)

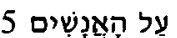

et leurs repères

על האנשים ה

וסימנהון

תכבד העבדה על האנשים

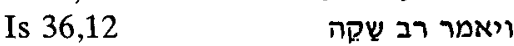

2 R 18,27

So 1,12 ופקדתי על ויכורו

1 Ch 19,5

למען ייארוך כל הימים b. Hayyim, (30); Ginsburg 'ain §

396; Weil, Mm 2347; Löwinger, Ch

\$ \$ \$ 140; Ognibeni, § 280 (106).

[Continuará] 